\title{
Exploring early childhood educators' notions about professionalism in Prince Edward Island
}

\author{
Alaina Roach O’Keefe, Sonya Hooper, and Brittany Jakubiec
}

\begin{abstract}
Dr. Alaina Roach O'Keefe is a sessional lecturer in the master of education program with the Faculty of Education and in the Faculty of Arts at UPEI. She is also employed as corporate HR planning consultant with the PEI Public Service Commission. Her background includes a bachelor of science (honours in psychology), a bachelor of education specializing in the early years, a master's in applied health research, and a PhD in educational studies. Her experiences as an educator and researcher over the last decade range from the early childhood and K-12 systems to postsecondary education as an early literacy specialist at the PEI Department of Education and Early Childhood Development, research analyst for several provincial government departments, sessional faculty member at UPEI, and learning manager at Holland College in the early childhood education and care program. Alaina's research interests include both quantitative and qualitative projects in education and early learning, health systems, strategic planning and evaluation, play as learning, diversity and inclusion, leadership, and action research in professional learning communities. Email: aroach@upei.ca
\end{abstract}

Sonya Hooper is the executive director of the Early Childhood Development Association of PEI. During her last ten years in this position she has had the pleasure of conducting research that has transformed policy and practice in early learning and child care, and she has organized and facilitated regional and local conferences and acted as co-chair to national conferences. Her background includes a diploma in early childhood care and education, a master's in education, and many years of early childhood professional experiences, including in kindergarten and special needs education, as well as creating and leading her own licensed child care facility for ten years. Sonya has developed and delivered many workshops. She participated as a panel speaker on the topic of constructing professionalism in four Canadian provinces at "International Innovations in ECE: A Canadian Forum on Early Childhood Frameworks," held in Victoria, BC, in July 2012, which led to her becoming a guest co-editor for Canadian Children's 2015 special issue on professionalism in ECEC.

Brittany A. E. Jakubiec is a PhD candidate in educational studies at the University of Prince Edward Island in Charlottetown. In her dissertation, she is exploring the identity formation process for LGBTQ+ adolescents in PEI. Brittany has a background in psychology and educational leadership, and she engages in a variety of research projects relating to education, social justice, and mental health. In her spare time, she spends time with her family and young son, and tries to read 52 books every year. 
Despite policy changes in a growing number of countries to increase the quality of early years education through the introduction of national curricular frameworks, conceptualizations of early childhood professionals remain distinctly variegated. Early learning curriculum frameworks have become embedded into the $21^{\text {st }}$-century early learning movement, creating a shift in professional deliverables and system expectations. This study explores how early childhood educators (ECEs) in Prince Edward Island (PEI) understand the concept of professionalism in their everyday practice. The researchers used qualitative methodology and a variety of methods, including workshops, interviews, and field notes, to gain insight into how ECEs understand professionalism. The data was analyzed through thematic analysis and understood through the lens of sociocultural theories of learning that embrace communities of practice as a positive way to promote professional learning. Primary findings explore (1) how ECEs understand professionalism in $P E I$, (2) positive and negative impacts on their understanding of professionalism in their daily practice, and (3) professional development opportunities that impact professionalism in the early childhood field.

Key words: early learning; early childhood education; professionalism; imposter syndrome
Around the world, early childhood education and care (ECEC) systems policy and practice have undergone great transformation (Flanagan, 2010, 2012; Goffin, 2013; Oberhuemer, 2013; Organisation for Economic Co-operation and Development, 2011). An increasing national and global emphasis on school readiness that positions ECEC as preparation for academic school success is underpinned by economically driven and narrowly construed views of cognition and learning (OECD, 2013, as cited in Alcock \& Haggerty, 2013, p. 21). Parallel to this schoolification, a corresponding focus on quality has also seen some reconceptualization and the terminology associated with the trained professionals working in the system has shifted, from babysitter to provocative protagonist, daycare worker to catalytic agent, and educator to mediator and facilitator (Edwards \& Gandini, 2015). Early learning curriculum frameworks have become embedded into the $21^{\text {st }}$-century early learning movement (Oberhuemer, 2013; Organisation for Economic Co-operation and Development, 2011), creating a shift in professional deliverables and system expectations. As Stacie Goffin (2013) writes, "never has more been expected of ECEs" (p. 42). Despite common policy growth and changes in a growing number of countries to raise the quality and visibility of early years services through the introduction of national curricular frameworks (Bennett, 2004; Blenkin, Rose, \& Yue, 1996; Burgess \& Fleet, 2009; Oberhuemer, 2005), conceptualizations of early childhood professionals remain distinctly variegated (Oberhuemer, 2005).

This article describes a study that explored how early childhood educators (ECEs) in Prince Edward Island (PEI), Canada, understand the concept of professionalism in their everyday practice. The researchers used qualitative methodology and a variety of methods, including workshops, interviews, and field notes, to gain insight into how ECEs understand professionalism.

PEI is a province on the east coast of Canada with a population of approximately 152,000. It has 46 governmentfunded early years centres and additional private options for daycare. The project described in this article followed nearly a decade of changes in the early childhood field in PEI, including a call for a comprehensive system overhaul of early learning and child care (ELCC) for preschool-aged children (in 2009), movement of kindergarten to the public school system (in 2010), and subsequent development of an early learning framework (Prince Edward Island Department of Education and Early Childhood Development, 2011) and the PEI Preschool Excellence Initiative (Prince Edward Island Department of Education and Early Childhood Development, 2009). The literature asserts that such dramatic change is not new (Ebbeck \& Clyde, 1988; Hayes, 2010). As Goffin (2013) explains, "given 
the upheavals early childhood education has experienced in 200 years of history, field altering change is not an anomaly" (p. xvii).

The purpose of this project was to unpack the professional notions and experiences that seasoned educators (i.e., with more than ten years of experience) have had as a result of many policy shifts and system changes over the past ten years in PEI. The research was guided by the following research questions: (1) What has changed in your profession since the implementation of the Preschool Excellence Initiative in PEI? (2) How have policy shifts impacted your understanding of your practice? (3) What other areas of professional growth are needed for ECEs?

In the next sections of this paper, the authors will illuminate threads of the research focusing on professionalism in the ELCC sector and in the PEI context.

\section{Professionalism in the early learning sector}

Internationally, numerous studies have delved into notions of professionalization in ECEC (e.g., Brock, 2012; Dalli, 2008; Lazzari, 2012; Urban, 2008). According to Goffin (2013), professional can be defined as committing to a job well done, being a good employee, providing a reliable, competent service, getting paid for what you do, and just plain good (Goffin, 2013). Traditionally, professionals were individuals who pursued a learned art in the spirit of public service; only incidentally did they view it as a means to secure a livelihood. Consequently, "professions have long been understood to be moral endeavors, demanding moderation on personal interests in order to provide beneficent service to others" (Weinberg, 2008, as cited by Feeney, 2012, p. 4).

Alongside notions of professionalism, since the 1990s significant discussion has taken place around notions of quality in the ECEC sector (Dahlberg, Moss, \& Pence, 2013). As this discussion has evolved the debates have continued to seek to define and measure quality in education and care (Dahlberg et al., 2013). In addition, notions of quality and professionalism have been embedded in various government policies, with the result that educators often feel watched, evaluated, or measured in a dynamic of power relations (Dahlberg et al., 2013; Osgood, 2006). This creation of standards and subsequent perceived gaze can lead to self-evaluation on the part of ECEs in their attempts to measure up to certain standards, and potentially results in imposter syndrome (Vergauwe, Wille, Feys, De Fruyt, \& Anseel, 2014).

Several decades of work (Katz, 1996, Spodek \& Saracho, 2003) in the early childhood field involved developing codes of ethics, credentialing, and examining ECEs' roles in relation to quality. Stephanie Feeney (2012), among others, has refined criteria involving ECEC; she denotes eight criteria to determine whether an occupation is a profession: a specialized body of knowledge and expertise, prolonged training, rigorous requirements for entry to training and eligibility to practice, standards of practice, commitment to serving a significant social value, recognition as the only group who can perform a function, autonomy, and a code of ethics. There is professionalism as individual practice, which both Feeney (2012) and Goffin (2013) discuss in the field of ECEC.

Feeney and other researchers suggest several areas in which ECEs demonstrate the ideals and principals of professionalism in their daily work with children. First, the notion of "knowledge and skills" refers to the specialized body of knowledge and skills that characterizes the unique contributions to society that ECEs make (Feeney, 2012; Spodek \& Saracho, 2003). Specialized knowledge and skills are very often the hallmark of a profession and are at the heart of their contribution to society (Goffin, 2013; Hordern, 2014). In the United States, the National Research Council (2001) recommended that all early childhood teachers have bachelor degrees (Bueno, Darling-Hammond, \& Gonzales, 2010). Yet, as Goffin (2013) articulates, "while formally acquired degrees and/or credentials are important to organized fields of practice, degrees and certifications by themselves do not denote professionalism" 
(p. 36). The second area, which Feeney (2012) calls "behaving like a professional," focuses on communication and relationship skills, work ethic, and professional codes of ethics (p. 58). Specific personal qualities or attributes are identified as being a critically important part of the ECE field (Feeney, 2012). Finally, "doing your best for young children" (Feeney, 2012, p. 86) is all about discovering your calling, being a life-long learner and a reflective practitioner, and having plans to always be a learner through your own professional development plan, in addition to being a "caring professional" (Taggart, 2011).

Carmen Dalli (2008, in collaboration with Cherrington) adds to this list of "cornerstones of professionalism specific to the EC field" (Cherrington, 2001, as cited in Dalli, 2008, p. 174) professionalism of interpersonal actions, having and acting on professional knowledge, acting in the child's best interest, and taking professional responsibility for the actions of one's colleagues. Dalli (2008) argues that traditional notions of EC work disempower the notion of professionalism in the field. Consistent with Feeney's work, Dalli and her colleague Lukmanul Hakim (Hakim \& Dalli, 2018) articulate that the journey to early childhood professional is one that involves more than a checklist and explores ways of thinking, being, and behaving.

Concomitant with the schoolification of the field and an increased emphasis on "quality," there has also been a focus on educators needing to assume a more intentional role in ECEC programs, as reinforced in curriculum frameworks. This expectation relates to Goffin's specialized body of knowledge, for the field is replete with language and key terms associated with early learning frameworks, such as scaffolding children's learning (Bodrova \& Leong, 2001), loose parts (Daly \& Beloglovsky, 2014), intentionality (Epstein, 2007), reflection (Edwards, Gandini, \& Forman, 1998), observation (Carr, 2001), pedagogical documentation (Rinaldi, 1998), and children's self-initiated actions and interests (Edwards et al., 1998). The push (resultant from the emphasis on quality) to create environments and relationships that inspire children to experiment, make choices, and guide their own learning means educators are encouraged to situate their practice within frameworks that perhaps they were not exposed to throughout their certificate or degree training (Goffin, 2013).

\section{Context of professionalism in the PEI early learning sector}

Coinciding with efforts to raise quality and visibility of the early years sector in PEI, the role of ECE was starting to be talked about as a "profession" rather than just an occupation. Campaigns like Start with Play (Early Childhood Development Association of Prince Edward Island, 2013) articulated that ECEs are early childhood professionals, that early learning is important, and that it ultimately happens through play. A cultural shift began to happen in PEI as ELCC was being discussed in numerous political and public platforms, thus placing system change on the agendas of families, educators, community advocates, policy makers, and academics. Professionalism was being defined through government policy, and ECEs were feeling reaffirmed by the message that they were professionals (Osgood, 2006). In addition, policy changes happened that were political in nature. For example, when PEI's government moved the previously community-based kindergarten system to the public school system, it required all kindergarten teachers to obtain a bachelor of education degree (if they did not already have one), created additional certification and training opportunities for ECEs to obtain two-year diplomas, implemented a wage scale and increase for ECEs in early years centres, and commissioned the creation of an early learning framework. The authors wondered if or how these changes would be implemented locally.

Observational data from the Early Childhood Development Association of PEI indicates that educators in the

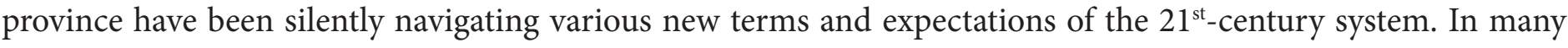
cases, educators confessed that they had set aside practices they used to have great confidence in, and practices such as circle time, work-jobs, group snack, and themes are now referred to as the "dirty words of daycare" (S. 
Hooper, personal communication, September 29, 2015), relics that belong in the past. Given the significant policy change and perceived shift in demands on educators working in the PEI ECEC system, some educators may be experiencing imposter syndrome (Bruno, Gonzalez-Mena, Hernandez, \& Sullivan, 2013; Vergauwe et al., 2014) and uncertainty about their practice. Imposter syndrome refers to the intense feelings of intellectual fraudulence often experienced by high-achieving individuals (Vergauwe et al., 2014). To investigate these issues further, the authors partnered to design and deliver a workshop series to support these educators in reflective practice and to formally document the process through a research study.

\section{Theoretical framework}

This work draws on sociocultural theories of learning which suggest that individuals learn through collaboration and that the co-construction of knowledge and thinking transpires through a shared interest or mission (Lave \& Wenger, 1991; Vygotsky, 1978). These theories embrace learning communities as a positive way to promote professional learning (Le Cornu \& Ewing, 2008). This study tapped into similar theories of professional learning which suggest that professional learning must be relevant, context based, and practical for educators to be effective (McGregor, Hooker, Wise, \& Devlin, 2010; Roach O'Keefe \& Moffatt, 2013). Sociocultural learning theories suggest that the experience PEI educators gained from participating in this practical short-term learning community may help them to recognize and acknowledge their funds of knowledge and to embrace their professionalism and responsibility to it. It may also enable a release from the paralysis they may have experienced in the recent years of policy shift in PEI.

A community of practice is defined as a group of people who share a common interest or profession (Lave \& Wenger, 1991). In this context, Etienne Wenger's (1998) characteristics of community of practice apply in that ECEs mutually engage in practice (coming together and creating a dialogue to explore and negotiate meanings of professionalism), doing so with a common purpose to learn and over a period of time to share experiences and stories together about their practice. Research suggests additional benefits of learning communities, such as a revived sense of positive professional identity and a decrease in feelings of isolation (Le Cornu \& Ewing, 2008; Roach O'Keefe \& Moffatt, 2013). Seasoned educators with more than 10 years in the field bring funds of knowledge to their practice that are mosaics of their education from many years ago combined with practical experience from working in the field (Moll, Amanti, Neff, \& González, 1992). The authors used this theoretical stance to explore notions around professionalism in the ELCC field in a setting where participants could both learn from and contribute to a collective dialogue. This methodological process is delineated in the next section.

\section{Methodology}

To explore professionalism in the ELCC sector in PEI, the researchers utilized a qualitative research methodology (Patton, 2014). The method used to examine the research questions reflects an ontological and epistemological perspective of learning as participation in a community of practice (Cherrington \& Thornton, 2013; Teague \& Anfara, 2012; Wenger, McDermott, \& Snyder, 2002). Questions were explored in a focus-group / small workshop fashion.

After receiving approval from the institutional research ethics board, an invitation was communicated to participants taking part in a professional development workshop series through the Early Childhood Development Association (ECDA). Initial data collection occurred at the first workshop, and interested participants were invited to follow up with an in-depth interview approximately three months later. Researchers made best attempts at purposive sampling to garner a wide variety of perspectives from both male and female ECEs representing PEI's 
three counties and Aboriginal, rural, and French centres, and to engage infant educators, preschool educators, special needs assistants, and directors with more than 10 years in the field. The aim was to recruit approximately 12 educators for these interviews, and 11 educators ended up participating. Despite efforts to have a representative sample, while the participants represented PEI's three counties, all 11 were female. Their length of experience in the field ranged from eight ${ }^{1}$ to 34 years in both public and private-licensed centres, and they brought expertise working with infant, preschool, and mixed-age groupings.

\section{Methods}

The researchers used multiple methods (see Figure 1) to collect data in two phases. Participants attended a professional learning workshop where researchers used an interview matrix to gather a large amount of information from participants in a short amount of time, build dialogue, and explore notions of professionalism and funds of knowledge. Using the results from the interview matrix, an in-depth interview protocol was developed and conducted with the educators. After the workshops and one-on-one interviews, the researchers brought back the data for member checking (Patton, 2014). In most cases, the participants agreed with the data as collected, chose not to add more, and approved the data. Researchers also made detailed and descriptive field notes and journal entries concerning their observations, reactions, direct quotations, insights, inspirations, and questions (Patton, 2014) before and promptly after the workshop. These field notes served as essential documents for data analysis.

After data collection, all three authors participated in thematic analysis of the data (Babbie, 2010; Neuendorf, 2017). To ensure the data collected within qualitative research is correctly interpreted by a research team and can be used to build new insights, it is vital that data analysis is conducted using best practices (Lincoln \& Guba, 1985) that support trustworthiness. Therefore, the thematic analysis involved two authors coding the data independently and identifying themes. The third author served as an independent member and consensus was built on the emergent themes. Findings and their significance, as well as explanations and conclusions, are discussed in subsequent sections of this paper.

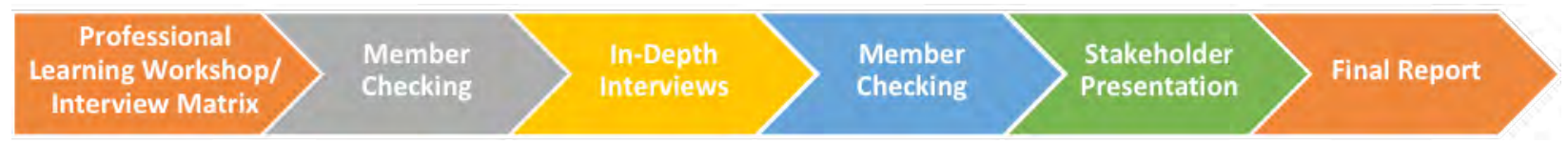

Figure 1. The research process.

\section{Findings}

While the researchers found many themes in the data, the most salient findings explore (1) how ECEs understand professionalism, (2) positive and negative impacts on their understanding of professionalism in their daily practice, and (3) professional development (PD) opportunities that impact professionalism in the EC field.

\section{How ECEs understand professionalism}

Participants talked about how their work was professional and an important part of economic growth. For example, Tara ${ }^{2}$ said:

We're recognized more professionally than babysitters. That's a bad word! There's more recognition that without childcare, people can't work. Without work, the economy is worse than it is now. 
Participants discussed what professionalism meant to them. They noted six ideas about what described professionalism: presentation, respect, high standards, values, training and a desire to improve, and policy support. First, presentation was important, in terms of attire:

Professionalism can mean lots of things-the way you speak, dress, and uphold yourself-but to me as an ECE I feel it's for me to provide the best care that I can to the child and the family, you know?" (April)

Another participant commented:

If you want to make $\$ 20$ an hour you're probably not going to do it in your pajamas. Unless it's pajama day, then it's totally fine! I just meant that if we want to be respected and want this pay and all this stuff, we need things to go with it. (Nick)

Extending this notion of looking like a professional was a second idea of being respected and respectful in their work with children and families and being respected by society:

Being respectful. To me it's having those open-ended conversations with children, families, and my director [...] focusing on the children and what their interests are. How they learn. And collaborating with everyone involved in that child's life to give them the best. (April)

The third idea was that there are high standards in their field, including working to the best of their ability to provide the best care to the child and the family:

You get so many different types of families too, like a family, whatever it may look like, whether it's a separated family or a same-sex family or refugee family ... you're there to support them and their needs. (April)

Professionalism to me is doing my job to the best of my ability, and that's what I strive to do every day [...] No matter what's going on in my life, when I walk in those doors it's all about the children. (Ezra)

In a related theme, participants spoke numerous times about values that one holds as an ECE, with patience, tolerance, thoughtfulness, honesty, reliability, and dedication being a few in particular that participants mentioned. Lainey spoke about these ideas:

There is a huge sense of pride to be working in this sector because years from now what we have shown these children how to conduct themselves, how to nurture, how to be patient, how to think of others and feel confident about themselves, they take throughout their whole life.

That these values would be modelled and passed along by the children gave them a sense that their work was very important.

Although Goffin claimed these do not denote a profession, participants also talked about education and training, qualifications, and the desire to improve as important components of professionalization in early childhood. As Ezra stated:

[It's important] that you have the qualifications. You can be straight out of college and still be more qualified than someone with a closed mind who's been there for 30 years. By being professional, I think it is the continuing education that you want, you have to want to be 
professional.

Finally, participants noted policies and early learning frameworks that support their work in the field. As Hana explained:

The policy shift has definitely helped professionalize practice; it set something out that everyone should aspire to, and if we're all doing our job well, we should all be on the same page in saying this is our core, this is what we should all be aspiring to.

Another participant, April, spoke about "now being able to speak to what I do with confidence."

\section{Experiencing system change: Impacts on understanding of professionalism}

System change (e.g., kindergarten leaving the early childhood system in PEI; the introduction of the Early Learning Framework) was something many participants wove into their discussions about professionalism and the changes they had experienced in the last decade. Participants articulated various reactions to change, both positive and negative. Some people embraced it and engaged in it as an opportunity for growth in their career and some had a hard time reconciling past learning with new expectations. April noted,

I felt when the changes came it really kind of separated people: you had the people who were doing the professional practice as they always did and this either bettered them or they just changed with it and embraced it, and then you had others who were certified and I hate, for lack of better term, were "old school." [The changes] terrified them, and [it] shut them down in their practice.

Anna noted that change was "okay" for those who were flexible and open-minded, and that it was time to either "step up or step back."

Kindergarten: Loss, grief, and readiness. The "loss" of kindergarten to the public school system was a recurring discussion throughout the project. When colleagues who were qualified ECEs became kindergarten teachers, educators who remained in the early childhood system grieved the loss of their mentors, friends, and co-workers and missed them dearly. Chris noted: "In the beginning it was extremely hard. Because we lost staff, we lost almost all of our certified staff; we lost probably half of our children." Hana added: "When kindergarten went into the school system, it sucked all of the certified early childhood educators that were there with it, pretty much out of the whole sector." Some participants remembered it being publicly stated by various people many times that "the best of the best [ECEs]" moved on to teach kindergarten in the public school system. Participating ECEs felt anger, with one stating that "it was a slap in the face professionally ... I don't know the ins and outs of it, but the bottom line, my assumption was that the government would rather put the money into the school system instead of here, where we need it" (Lainey). Educators discussed that while there were programs put in place ("the Golden Carrot") for the kindergarten teachers to obtain their degree, and for the uncertified staff left in the system to obtain their 90-hour certification and/or diplomas, they were the ones left holding the sector together and no one had thanked them for staying. Many of the participants also expressed that they stayed to teach in the early childhood sector because they wanted to, because they loved what they did and were good at it.

Schoolification. Schoolification was a term that participants discussed in connection with kindergarten leaving their system and moving to the public school system. What they meant by the term is that as a result of certain policies there is now more focus on academic learning and less on developmentally appropriate practice (Pardo \& Woodrow, 2014). The participants spoke about how they perceived a shift in parents' and society's expectations 
of children. They said that kindergarten readiness (which they viewed as a "dirty word") seemed to be a focus of late, and that this was causing stress and threatening their professional pedagogy about how young children learn. When ECEC is schoolified, then what ECEs saw as integral to their practice was lost. Lainey said she felt "very strongly that we are here to teach a lot of social skills, self-regulation, self-control, empathy, sensitivity, tolerance ...we're stepping in, guiding, we're scaffolding, and when they get to school it becomes very much an academic focus.”

Tensions around documentation. Participants also talked about the introduction of pedagogical documentation as something they valued, which they felt was rewarding (to see the evolution of the child) and helped them scaffold learning. However, they also recounted that the perceived increased pressure to document (and assess) everything was taking away from enjoying the experience with the child (e.g., they spoke about feeling that they needed to take notes, take more pictures, etc.). They also spoke about the frustration they felt that "the more kids, the more difficult it is" because they had limited time to complete binders (portfolios) for each child, and the quality, thought, and effort they wanted to put into it was limited because of the volume of children and the amount of documentation they felt was required. They also were discouraged when they created documentation of children's learning for families and "parents didn't look at the documentation binders ... I'm disappointed by this" (Janet). Participants also spoke of the pressure to prove their professionalism ("We are really teaching!") through their practice of documentation. For example, Cheryl talked about tying pedagogical documentation to the early learning framework outcomes so that parents and caregivers could see that the children were actually learning: "I know the parents want structure over play because when they think of play they think we're just babysitting and we're just housing the children."

Imposter syndrome and professional confidence. There was evidence in the transcripts and in multiple discussions through the course of this project that there are educators who feel confident in their profession but also those who are struggling with imposter syndrome. Persistent confusion about what is expected of them and feeling like they are fraudulent in their practice is part of what underlies much of their frustration about the current state of their profession in PEI (Vergauwe et al., 2014).

Well, in college we were taught you pick your theme and we had to plan a whole week, so many activities for this, you go outside, what can I bring outside to continue my theme? You had to do the whole week ahead of time. Then the framework came into place and it was like no, you go with the interests of the children, so then it was like, what? What do we do with all this planning that we were taught to do? So there was kind of a period of confusion. It was like, do I keep my themes, do I keep doing what I was doing, or we thought we had to stop that and observe the kids and see what they like to do, and we didn't really understand the framework, we didn't know what to do with it! So it was very confusing [...] Like, lost. And we were angry, we were frustrated, because it was another thing put on us, you know? [Sigh] Anyway ... it was frustrating because we didn't understand it because maybe we didn't [pause] learn the right way, or nobody showed us in a way that we could understand it and how to apply it with what the kids were doing, and so we kind of rebelled a bit, you know? (Janet)

Growing respect. Some participants also articulated that change came with some positive things for the early childhood profession in the form of growing respect for ECEs (by parents, community, and government officials). For example, Lainey said:

In the last 5 to 10 years, parents and community are starting to understand the importance that we have and the knowledge that we need in order to work in this sector [of EC] ... it used to 
be a joke ... but now they are seeing us as being very knowledgeable about child development, children's social behaviours ... empowerment.

Paradoxically, then, while some participants felt less confident, they did perceive that the public was starting to see them as professionals.

\section{PD opportunities that impact professionalism}

Finally, the participants identified what they needed to continue advancing their profession as early childhood educators, and what they wanted or needed in order to continue in their own professional journey. Participants articulated requests for advocacy in their responses to what their suggestions for professional growth included. These comprised the need for matching professional expectations (around pedagogical documentation) with actual resources. Hana stated, "we need work time and substitutes for planning time," while Nick commented, "I am still in the same place I was in 15 years ago where I am going out and buying supplies on my own dollar." Some participants noted a need for better communication within and beyond the EC sector with partners (e.g., referral processes for children with special needs). Lainey said:

It's a big thing right now that all these children in the centre that we're trying to reach out to but we just don't have enough time in our day and enough bodies to give the support that they need. To take it outside of our sector, we don't have the speech pathologist or don't have a speech pathologist in our area, we don't have access to an OT as needed or a child psychologist as we need it, and we really need our own.

Tina articulated the impetus to leverage technology better within their practice, particularly using "social media (e.g., Facebook) to talk with parents to post pictures." Others said they wanted parity with teachers in the formal school system (e.g., access to similar benefits and privileges); Nick mentioned "closing the childcare centres when schools are closed and flu shots for free like the teachers," as well as more access to grants, etc., for play supplies: "it would be great if there was a grant for each of us to get our own computer." Janet suggested increased access to "accessible professional development (e.g., PD sessions, access to bursaries for higher education).

\section{Discussion}

The purpose of this study was to explore how ECEs in PEI understand the concept of professionalism in their everyday practice. Findings were supported in numerous ways by the previous work in this area; they also offer new opportunities for the field. These are discussed in the sections below: fostering resilience and workplace wellness through emotional intelligence (EQ); motivating a marginalized field; encouraging pedagogical practices; and developing leaders in the EC field.

\section{Fostering resilience and workplace wellness through emotional intelligence (EQ)}

Imposter syndrome and educators' lack of intrinsic motivation can be linked to burnout (Gu \& Day, 2007). Research also identifies factors that contribute to employee resilience and success, including professional mentorship, collegiality, celebrating one another's expertise and professional importance, and personal commitment to ongoing learning and self-insight (Sumison, 2004). Employer support to create such an environment can result in educators feeling healthier, more motivated, and more autonomous (Sumison, 2004; Timperley, Wilson, Barrar, \& Fung, 2007), which can, in turn, be useful for recruiting and retaining quality ECEs through decreased perceived stress (Wagner et al., 2012). In addition, through continued collaborative learning communities, ECEs can build resilience and develop an awareness of their EQ, that is, their emotional responses "as one of their many ways of 
knowing, and using the power of emotion as a basis of collective and individual social resistance, teachers can sort their experiences, their anxieties, their fears, their excitements and learn how to use them in empowering ways" (Zembylas, 2003, p. 231). There is an opportunity to build a better workforce through fostering emotional intelligence (EQ) in new ways for ECEs.

An important facet of professionalism is autonomy, which is linked to psychologically healthy workplaces. Decision makers need to pay attention to early childhood educators' psychological well-being at work, as it depends on their feelings of autonomy, and without it, they are at risk of becoming unwell (Royer \& Moreau, 2015). In addition, mental health in the workplace is important if childcare centres are to be the healthy, safe, and exciting places they are intended to be. To nurture and foster good mental health in children, educators need to be nurtured themselves and to practice self-care; research asserts that the personal and professional selves are intertwined (Osgood, 2012; Sumison, 2004).

Ann Masten writes: "Resilience has often been defined as the ability to bounce back in times of adversity and to develop in a positive way when faced with setbacks" (2009, as cited in Petty, 2014, p. 35). The grief, anger, and sadness that educators are feeling amidst change in their profession over the last decade align with the stages of grief identified by Elisabeth Kübler Ross (2005), whose model includes denial, anger, bargaining, depression, and acceptance. The educators' frustration with the changes over the past decade signals a need for those who can support them to respond with provision or with help. The voice of resilience (i.e., educators' acceptance of change and their willingness to grow) needs to be championed, and there are opportunities here for mentoring within the sector like never before.

\section{Motivating a marginalized field}

Participants voiced their desire to remain firmly rooted in the ELCC sector after the changes in kindergarten and the introduction of the PEI Preschool Excellence Initiative. They talked about having discovered their calling, as Feeney (2012) calls it, and having plans to grow and learn. However, this and other comments reflect a professional motivation that is extrinsic in nature. Many of the educators spoke of having an early childhood mentor of some kind who they relied on to tell them if they were doing something right or not (e.g., how they implement new curriculum). This is not uncommon when the dominant construction of professionalism has been through government policy, leaving educators perceiving they are subject to a Foucauldian regulatory gaze (Osgood, 2006).

Participants also articulated having wanted some kind of recognition for their practice. For example, Cheryl said, "No one thanked us for staying." While it is not unusual to want such recognition, especially after they saw it being given to others (kindergarten teachers, uncertified staff who were going back to school), these educators relied on external recognition to provide them with the professional sustenance of confidence they perhaps were lacking. Underlying the extrinsic motivation and need for approval are remnants of the oppressed (Freire, 1968) where these individuals feel that they are being told what to do, and that their role is inferior in some way. How do we get beyond the deeply engrained notions of care versus education when some of these educators might not buy into this notion themselves? This finding aligns with Dalli's $(2002,2008)$ assertion that the very traditional alignments of early childhood work have potentially disempowered ECEs from asserting their professional status.

When intrinsic motivation in early childhood educators is activated, the authors saw them become passionate, articulate, and empowered as they spoke of their profession. Nurturing this intrinsic motivation and fostering opportunities that encourage educators to use their voice is important, as is creating occasions where they can take back their power and rekindle their passion for what they love most. Taking part in such opportunities as an early childhood educator might help in building this capacity within the ELCC sector. This indicates that there is also an 
opportunity to create opportunities and mechanisms where early childhood educators can explore these notions of power and talk about their role as professionals.

\section{Encouraging pedagogical practices}

Pedagogical documentation was frequently mentioned in the findings above, but participants suggested that it comes with a price: a need for additional resources. Pedagogical documentation was developed in the 1970s and 1980s by the educators of the infant-toddler centres and preschools of the municipality of Reggio Emilia in northern Italy and has spread worldwide (Edwards et al., 1998). The process of pedagogical documentation supports educators in both including child development in their view and in looking beyond development to capture broader aspects of experience for reflection. Pedagogical documentation opens us up to relations and meanings that we have not thought to look for. As Carol Anne Wien (2013, p. 2) suggests, this expansion of what we might learn to know and interpret is its gift to us.

As educators reclaim their professional voices and strengthen their theoretical knowledge of the practical applications of their profession, they will find this helpful to be able to better communicate the purpose and longterm goals of early learning and care to others (other educators, families, etc.). Participants expressed that they did this through pedagogical documentation, but also voiced the need to be supported in this. When ECEs use their voices and their specialized banks of knowledge and skills to articulate developmentally appropriate practice and reflective pedagogy, they strengthen their position of power. This would work to help them push up instead of feeling the push-down of developmentally inappropriate expectations and practice. This finding is congruent with Dalli’s (2008) findings around pedagogical strategies that are "professionally desirable" (p. 177).

\section{Developing leadership in the EC field through PLCs}

The participating educators discussed Feeney's (2012) notion of professionalism as individual practice; however, contrary to Feeney's work, they did not mention the specialized body of knowledge and skills as a characteristic, nor did they discuss this at any other point in the workshops, during member checking, or during interviews with researchers. This gap illuminates a glaring requirement to provide a foundation of language about professionalism in postsecondary training. For example, professional development opportunities could support these ECEs to articulate what they do and why they do it, and to articulate their pedagogy and specialized competencies that demonstrate their expertise and professionalism.

Related to the findings of educators' desire to increase both their professional confidence (vs. imposter syndrome) and their access to quality professional development for career advancement is the notion of the need to develop leadership in the ELCC field. As suggested by several pieces of research, one of the single most important predictors of educational institutions is the strength of its leader(s) (Day \& Sammons, 2013), in particular the strength of its pedagogical leadership (Andrews, 2009; Coughlin \& Baird, 2014; Wenger, 1998). With all of the system change that has occurred in PEI, directors of ELCC centres are left as the primary mentors of their staff on a daily basis. Support for directors is required, and was articulated as a key piece for moving forward with the PEI Preschool Excellence Initiative. The opportunity is ripe. Directors have tools and are able to be effective leaders in the early childhood field. Expert professional development in areas of pedagogical coaching, leadership, change leadership, and other areas in which they express a need for further learning and development would only strengthen the support directors are able to provide. Although this research involves a small sample of early childhood educators and directors in PEI, it was clear that some directors are thirsting for additional knowledge, not only to help them support the ECEs who serve the children in their centres, but also for personal and professional satisfaction and confidence to become the leaders of the ELCC system of tomorrow. There are important signals for continued 
growth of professional learning communities as a means of professional development, specifically for leadership development within this ELCC community (Teague \& Anfara, 2012).

\section{Educational significance}

In the short term, the findings from this project help to articulate how ECEs in PEI understand the concept of professionalism in their everyday practice. Findings may also inform the future design of professional learning opportunities for these educators who have 10 or more years of experience. In the long term, the findings from this project will add to the body of research that has been supported and validated by the ECDA and contribute to the knowledge surrounding professionalism of ECEs in PEI and Canada. The research may also serve to (1) renew dialogue about professionalism in the ECEC field in PEI; (2) prompt a dialogue about next steps for the PEI initiative(s) (e.g., long-term communities of practice [Cherrington \& Thornton, 2013; McGregor et al., 2010; Powell, Diamond, \& Cockburn, 2013], workplace wellness, and recognition strategies); and (3) serve as an evidence-informed discussion that may be used to begin a planning process for the development of postsecondary learning initiatives and to build dialogue about what a truly professional ELCC community in PEI would look like. Results from this study also contribute to both national and international work in this area, enriching the dialogue of professionalism in the ELCC field and prompting a call for deeper critical discussion in this area. 


\section{References}

Alcock, S., \& Haggerty, M. (2013). Recent policy developments and the "schoolification" of early childhood care and education in Aotearoa New Zealand. Retrieved from http://www.nzcer.org.nz/system/files/ECF2013_2_021_1.pdf

Andrews, M. (2009). Managing change and pedagogical leadership. In A. Robins \& S. Callan (Eds.), Managing early years settings: Supporting and leading teams (pp. 45-64). London, UK: SAGE.

Babbie, E. (2010). The practice of social research. Belmond, CA: Wadsworth Cengage.

Bodrova, E., \& Leong, D. J. (2001). Tools of the mind: A case study of implementing the Vygotskian approach in American early childhood and primary classrooms. Geneva: International Bureau of Education.

Bennett, J. (2004). Curriculum issues in national policy-making. Keynote address, EECERA conference, Malta. Paris, France: OECD.

Blenkin, G. M., Rose, J., \& Yue, N. (1996). Government policies and early education: Perspectives from practitioners. European Early Childhood Education Research Journal, 4(2), 5-19. doi:10.1080/13502939685207891

Brock, A. (2012). Building a model of early years professionalism from practitioners' perspectives. Journal of Early Childhood Research, $11(1), 27-44$.

Bruno, H. E., Gonzalez-Mena, J., Hernandez, L. A. \& Sullivan, D. R.-E. (2013). Learning from the bumps in the road: Insights from early childhood leaders. St. Paul, MN: Redleaf.

Bueno, M., Darling-Hammond, L., \& Gonzales, D. (2010). A matter of degrees: Preparing teachers for the pre-K classroom. Washington, DC: Pre-K Now.

Burgess, J., \& Fleet, A. (2009). Frameworks for change: Four recurrent themes for quality in early childhood curriculum initiatives. AsiaPacific Journal of Teacher Education, 37(1), 45-61. doi:10.1080/13598660802534489

Carr, M. (2001). Assessment in early childhood settings: Learning stories. London, UK: Paul Chapman.

Cherrington, S., \& Thornton, K. (2013). Continuing professional development in early childhood education in New Zealand. Early Years, 33(2), 119-132. doi:10.1080/09575146.2013.763770

Coughlin, A. M., \& Baird, L. (2014). Pedagogical leadership. Retrieved from http://www.edu.gov.on.ca/childcare/Baird_Coughlin.pdf

Dalli, C. (2002). Being an early childhood teacher: Images of professional practice and professional identity during the experience of starting childcare. New Zealand Journal of Educational Studies, 37(1), 73-85.

Dalli, C. (2008). Pedagogy, knowledge and collaboration: Towards a ground-up perspective on professionalism. European Early Childhood Research Journal, 16(2), 171-185.

Daly, L., \& Beloglovsky, M. (2014). Loose parts: Inspiring play in young children. St. Paul, MN: Redleaf.

Dahlberg, G., Moss, P., \& Pence, A. (2013). Beyond quality in early childhood education and care: Languages of evaluation ( $3^{\text {rd }}$ ed.). New York, NY: Routledge.

Day C., \& Sammons, P. (2013). Successful leadership: A review of the international literature. Retrieved from https://files.eric.ed.gov/ fulltext/ED546806.pdf

Early Childhood Development Association of Prince Edward Island. (2013). Start with play. Retrieved from http://startwithplay.ca/en/

Ebbeck, M., \& Clyde, M. (1988). Early childhood teaching: The disintegrated profession? Early Child Development and Care, 34, 279-285.

Edwards, C. P., \& Gandini, L. (2015). Teacher research in Reggio Emilia: Essence of a dynamic, evolving role. Voices of Practitioners, 89-114. Retrieved from http://digitalcommons.unl.edu/cgi/viewcontent.cgi?article=1108\&context=famconfacpub

Edwards, C., Gandini, L., \& Forman, G. (1998). The hundred languages of children: The Reggio Emilia approach to early childhood education. Norwood, NJ: Ablex. 
Epstein, A. S. (2007). The intentional teacher: Choosing the best strategies for young children's learning. Washington, DC: National Association for the Education of Young Children.

Flanagan, K. (2010). The early years report. Early learning in PEI: Investment in the island's future. Retrieved from http://www.gov.pe.ca/ photos/original/edu_earlyyrsRpt.pdf

Flanagan, K. (2012). Changing the discourse: Perspectives from Canada. Paper presented at "International Innovations in ECE: A Canadian Forum on Early Childhood Frameworks," Victoria, BC, July 13-15.

Feeney, S. (2012). Professionalism in early childhood education: Doing our best for young children. New York, NY: Pearson Education.

Freire, P. (1968). Pedagogy of the oppressed. New York, NY: Continuum International.

Goffin, S. (2013). Early childhood education for a new era: Leading for our profession. New York, NY: Teachers College Press.

Gu, Q., \& Day, C., (2007). Teachers resilience: A necessary condition for effectiveness. Teaching and Teacher Education, 23(8), $1302-1316$.

Hakim, L., \& Dalli, C. (2018). “To be professional is a never-ending journey”: Indonesian early childhood practitioners' views about the attitudes and behaviours of a professional teacher. Early Years, 38(3), 244-257.

Hayes, N. (2010). Childcare? Early childhood education and care? Towards an integrated early years policy for young children in Ireland. Early Years, 30(1), 67-78. doi:10.1080/09575140903503068

Hordern, J. (2014). Knowledge, practice, and the shaping of early childhood professionalism. European Early Childhood Education Research Journal, 24(4), 508-520. doi:10.1080/1350293X.2014.975939

Katz, L. (1996). Child development knowledge and teacher preparation: Confronting assumptions. Early Childhood Research Quarterly, $11,135-146$.

Kübler-Ross, E. (2005). On grief and grieving: Finding the meaning of grief through the five stages of loss. New York, NY: Simon \& Schuster.

Lave, J., \& Wenger, E. (1991). Situated learning: Legitimate peripheral participation. Cambridge, UK: Cambridge University Press.

Lazzari, A. (2012). Reconceptualising professionalism in early childhood education: Insights from a study carried out in Bologna. Early Years, 32(3), 252-265.

Le Cornu, R., \& Ewing, R. (2008). Reconceptualizing professional experiences in pre-service teacher education: Reconstructing the past to embrace the future. Teaching and Teacher Education, 24(7), 1799-1812.

Lincoln, Y. S., \& Guba, E. G. (1985). Naturalistic inquiry. Beverly Hills, CA: SAGE.

McGregor, D., Hooker, B., Wise, D., \& Devlin, L. (2010). Supporting professional learning through teacher educator enquiries: An ethnographic insight into developing understandings and changing identities. Professional Development in Education, 36(1/2), 169-195. doi:10.1080/19415250903457117

Moll, L., Amanti, C., Neff, D., \& González, N. (1992). Funds of knowledge for teaching: Using a qualitative approach to connect homes and classrooms. Theory into Practice, 31(2), 132-141.

National Research Council. (2001). Eager to learn: Educating our preschoolers. Committee on Early Childhood Pedagogy. B. T. Bowman, M. S. Donovan, \& M. S. Burns (Eds.), Commission on Behavioural and Social Sciences and Education. Washington, DC: National Academy Press.

Neuendorf, K. (2017). The content analysis guidebook. Thousand Oaks, CA: SAGE.

Oberhuemer, P. (2005). Conceptualising the early childhood pedagogue: Policy approaches and issues of professionalism. European Early Childhood Education Research Journal, 13(1), 5-16. doi:10.1080/13502930585209521

Oberhuemer, P. (2013). Continuing professional development and the early years workforce. Early Years, 33(2), 103-105. doi:10.1080/0 9575146.2013.793483 
Organisation for Economic Co-operation and Development. (2011). Encouraging quality in early childhood education and care (ECEC). Retrieved from http://www.oecd.org/education/school/48623811.pdf

Osgood, J. (2006). Deconstructing professionalism in early childhood education: Resisting the regulatory gaze. Contemporary Issues in Early Childhood, 7(1), 5-14. doi:10.2304/ciec.2006.7.1.5

Osgood, J. (2012). Narratives from the nursery: Negotiating professional identities in early childhood. London, UK: Routledge.

Pardo, M., \& Woodrow, C. (2014). Improving the quality of early childhood education in Chile: Tensions between the public policy and teacher discourse over the schoolarisation of early childhood education. International Journal of Early Childhood, 46, 101-115.

Patton, M. (2014). Qualitative research and evaluation methods (4 ${ }^{\text {th }}$ ed.). Thousand Oaks, CA: SAGE.

Petty, K. (2014). Ten ways to foster resilience in young children: Teaching kids to "bounce back." Dimensions of Early Childhood, 42(3) 34-39.

Powell, D. R., Diamond, K. E., \& Cockburn, M. K. (2013). Promising approaches to professional development for early childhood educators. In O. N. Saracho \& B. Spodek (Eds.), Handbook of research on the education of young children ( $3^{\text {rd }}$ ed.). New York, NY: Routledge.

Prince Edward Island Department of Education and Early Childhood Development. (2011). PEI early learning framework: Relationships, environments, experiences. Retrieved from http://www.gov.pe.ca/eecd/eecd_EYFrWrk_Full.pdf

Prince Edward Island Department of Education, Early Learning, and Culture. (2009). Securing the future for our children: Preschool Excellence Initiative. Retrieved from https://www.princeedwardisland.ca/sites/default/files/publications/eelc_preschool_ excellence_initiative.pdf

Rinaldi, C. (1998). Projected curriculum and documentation. In C. Edwards, L. Gandini \& G. Forman (Eds.), The hundred languages of children: The Reggio Emilia approach-Advanced reflections (pp. 113-125). Stamford, CT: Ablex.

Roach O'Keefe, A., \& Moffatt, L. (2013). Where to start?: Early childhood educators, digital literacies, and professional learning final report. Charlottetown, PE: University of PEI.

Royer, N., \& Moreau, C. (2015). A survey of Canadian early childhood educators' psychological well-being at work. Early Childhood Education Journal, 44(2), 135-146. doi:10.1007/s10643-015-0696-3.

Spodek, O., \& Saracho, B. (Eds.). (2003). Studying teachers in early childhood settings. Greenwich, CT: Information Age.

Sumison, J. (2004). Early childhood teachers' constructions of their resilience and thriving: A continuing investigation. International Journal of Early Years Education, 12(3), 276-290.

Taggart, G. (2011). Don't we care?: The ethics and emotional labour of early years professionalism. Early Years, 31(1), 85-95. doi.org/10. $1080 / 09575146.2010 .536948$

Teague, G. M., \& Anfara, V. A., Jr. (2012). Professional learning communities create sustainable change through collaboration. Middle School Journal, 44(2), 58-64.

Timperley, H., Wilson, A., Barrar, H., \& Fung, I. (2007). Teacher professional learning and development: Best evidence synthesis iteration. Wellington, New Zealand: Ministry of Education. Retrieved from https:/www.educationcounts.govt.nz/publications/ series/2515/15341

Urban, M. (2008). Dealing with uncertainty: Challenges and possibilities for the early childhood profession. European Early Childhood Education Research Journal, 16(2), 135-152.

Vergauwe, J., Wille, B., Feys, M., De Fruyt, F., \& Anseel, F. (2014). Fear of being exposed: The trait-relatedness of the impostor phenomenon and its relevance in the work context. Journal of Business Psychology, 30, 565-581. doi:10.1007/s10869-014-9382-5

Vygotsky, L. S. (1978). Mind in society: The development of higher psychological processes (M. Cole, V. John-Steiner, S. Scribner, \& E. Souberman, Eds.). Cambridge, UK: University of London Press. 
Wagner, S., Forer, B., Cepeda, I., Goelman, H., Maggi, S., D’Angiulli, A., ... \& Grunau, R. (2012). Perceived stress and Canadian early childcare educators. Child and Youth Care Forum, 42, 53-70.

Wenger, E. (1998). Communities of practice: Learning, meaning, and identity. Cambridge, UK: Cambridge University Press.

Wenger, E., McDermott, R., \& Snyder, W. M. (2002). Cultivating communities of practice. Boston, MA: Harvard Business School Press.

Wien, C. A. (2013). Making learning visible through pedagogical documentation. Retrieved from http://www.edu.gov.on.ca/childcare/ wien.pdf

Zembylas, M. (2003). Emotions and teacher identity: A poststructural perspective. Teachers and Teaching, 9(3), $213-238$.

\section{(Endnotes)}

1 Despite the aim to recruit those with 10 or more years' experience.

2 Note: All participant names in this article are pseudonyms. 